\title{
Pathogenicity of Corynespora cassiicola on different hosts in Amazonas State, Brazil
}

\author{
Ana Francisca Tibúrcia Amorim Ferreira e Ferreira ${ }^{1}$ \& Jânia Lília da Silva Bentes ${ }^{1}$
}

${ }^{1}$ Federal University of Amazonas - FCA, Manaus, AM. 69077-000, Brasil

Autor para correspondencia: Jânia Lília da Silva Bentes (jlbentes@ufam.edu.br)

Data de chegada: 26/08/2016. Aceito para publicação em: 16/09/2016 .

$10.1590 / 0100-5405 / 2220$

\section{ABSTRACT}

Ferreira, A.F.T.A.F.; Bentes, J.L.S. Pathogenicity of Corynespora cassiicola on different hosts in Amazonas State, Brazil. Summa Phytopathologica, v.43, n.1, p.63-65, 2017.

Target spot, caused by the fungus Corynespora cassiicola, occurs endemically in Amazonas State, leading to reduced production in several crops. This study evaluated the pathogenicity of C. cassiicola isolates in tomato, eggplant and papaya. Isolates were obtained from crop areas in the cities of Manaus, Iranduba and Presidente Figueiredo in Amazonas State. The disease severity was assessed, as well as the number and the diameter of lesions. Experimental design was completely randomized in a factorial

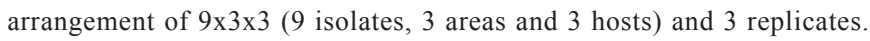
Papaya isolates caused symptoms in all evaluated plant species, and a certain degree of specificity was demonstrated for eggplant and tomato isolates, which did not cause disease in papaya. Severity was higher in tomato plants. The isolates obtained from Iranduba were most aggressive, suggesting that the geographic origin influenced the aggressiveness of isolates.

Palavras-chave: target spot, cross pathogenicity, specificity.

\section{RESUMO}

Ferreira, A.F.T.A.F.; Bentes, J.L.S. Patogenicidade de Corynespora cassiicola em diferentes hospedeiros no Estado do Amazonas. Brasil. Summa Phytopathologica, v.43, n.1, p.63-65, 2017.

A mancha-alvo, causada pelo fungo Corynespora cassiicola, ocorre de forma endêmica no estado do Amazonas, levando à redução na produção em diversas culturas. Neste trabalho foi avaliada a patogenicidade de isolados de C. cassiicola em plantas de tomate, berinjela e mamão. Os isolados foram obtidos em áreas produtoras nos municípios de Manaus, Iranduba e Presidente Figueiredo no Amazonas. Foram avaliadas a severidade da doença, o número e diâmetro das lesões. $\mathrm{O}$ delineamento experimental foi inteiramente casualizados, em esquema fatorial 9x3x3 (9isolados, 3 áreas e 3 hospedeiros) com três repetições. Os isolados de mamão causaram sintomas em todas as espécies de plantas avaliadas, e certo grau de especificidade foi demonstrado nos isolados de berinjela e tomate, que não causaram doença em mamão. A severidade da doença foi maior em tomate. Os isolados obtidos de Iranduba foram os mais agressivos, sugerindo que a origem geográfica influenciou a agressividade dos isolados.

Keywords: mancha alvo, patogenicidade cruzada, especificidade.

The fungus Corynespora cassiicola (Berk. \& Curt.) C. T, Wei, is the causal agent of target spot or Corinespora spot disease. It is widely distributed in the tropics and has as host plants approximately 530 species among different genera. In Brazil, the disease causes economic damage to crops such as antilles cherry (Malpighia glabra), cocoa (Theobroma cacao), papaya (Carica papaya), cucumber (Cucumis sativus), rubber tree (Hevea brasiliensis), soybean (Glycine max) and tomato (Solanum lycopersicum) (4). In the north of the country, tomato yield is usually made by small holders in areas that already contain other crops such as cucumber, peppers, eggplant and papaya, which are host plants of C. cassiicola. Pathogenicity tests, i.e. inoculations in several hosts to characterize the isolates according to the pathogenicity, allow identifying both the range of the pathogen's host species and the presence of host specificity, which were already done for C. cassiicola $(1,7)$. Pathogenic characterization studies with $C$. cassiicola have shown different reactions among the tested species and identified the occurrence of physiological races (9). The aim of this study was to evaluate the pathogenicity of different isolates of $C$. cassiicola in tomato, papaya and eggplant. Our hypothesis is that isolates of $C$. cassiicola have different behavior depending on the host or on the geographic origin.

The experiments were conducted in the Laboratory of Microbiology and Plant Pathology and Production Sector of the Faculty of Agrarian Sciences of the Federal University of Amazonas. For the evaluation, nine isolates of $C$. cassiicola obtained from the leaves of tomato (isolate 1,2 and 3), eggplant (isolate 4, 5 and 6) and papaya (7, 8 and 9) were collected in the cities of Manaus, Iranduba and Presidente Figueiredo. Indirect isolation of the pathogen was performed on Petri dishes containing PDA culture medium $\left(\mathrm{KASVI}^{\circledR}\right)$. C. cassiicola was identified by observing reproductive structures under a microscope (Zeizz Primo Star), 40X objective, and by comparing the findings with data in the literature (3). To ensure greater genetic uniformity, monosporic colonies were obtained. For the pathogenicity tests, tomato (Santa Cruz Kada Gigante), eggplant (Ciça hybrid) and papaya plants (variety Sunrise Solo) were used in cross inoculations of nine isolates of the fungus in their original host and in the other species. Seedlings were prepared in polystyrene trays containing the commercial substrate VIVATTO Slim ${ }^{\circledR}$. The plants were transplanted to 1-liter plastic bags containing $30 \%$ commercial substrate and $70 \%$ compost, when they had two true leaves for eggplant and tomato, and four true leaves for papaya. 
Table 1. Severity of Coynespora cassiicola isolates on different hosts in Amazonas.

\begin{tabular}{|c|c|c|c|c|c|c|c|c|c|}
\hline \multirow[t]{2}{*}{ Isolates } & \multicolumn{3}{|c|}{ Number of lesion } & \multicolumn{3}{|c|}{ Diameter of lesion } & \multicolumn{3}{|c|}{ Severity* } \\
\hline & Tomato & Eggplant & Papaya & Tomato & Eggplant & Papaya & Tomato & Eggplant & Papaya \\
\hline 2 (TO-Ira) & $103.333 \mathrm{Bb}$ & $204.000 \mathrm{Aa}$ & $0.000 \mathrm{Ca}$ & $1.370 \mathrm{Aa}$ & $0.433 \mathrm{Ba}$ & $0.000 \mathrm{Bb}$ & $1.954 \mathrm{Aa}$ & $2.121 \mathrm{Aa}$ & 0.000 \\
\hline 4 (EG-Mao) & $66.333 \mathrm{Bb}$ & $125.333 \mathrm{Aa}$ & $0.000 \mathrm{Ca}$ & $1.767 \mathrm{Aa}$ & $0.440 \mathrm{Ba}$ & $0.000 \mathrm{Bb}$ & $1.954 \mathrm{Aa}$ & $1.954 \mathrm{Aa}$ & 0.000 \\
\hline 5 (EG-Ira) & $325.000 \mathrm{Aa}$ & $144.667 \mathrm{Ba}$ & $0.000 \mathrm{Ca}$ & $0.853 \mathrm{Aa}$ & $0.393 \mathrm{Ba}$ & $0.000 \mathrm{Bb}$ & $2.121 \mathrm{Aa}$ & $1.954 \mathrm{Aa}$ & 0.000 \\
\hline 6 (EG-PF) & $56.333 \mathrm{Bb}$ & $141.000 \mathrm{Aa}$ & $0.000 \mathrm{Ba}$ & $1.277 \mathrm{Aa}$ & $0.517 \mathrm{Ba}$ & $0.000 \mathrm{Bb}$ & $1.954 \mathrm{Aa}$ & $1.858 \mathrm{Aa}$ & 0.000 \\
\hline 8 (PA-Ira) & $41.000 \mathrm{Bb}$ & $123.667 \mathrm{Aa}$ & $3.667 \mathrm{Ba}$ & $1.340 \mathrm{Aa}$ & $0.287 \mathrm{Ba}$ & $1.017 \mathrm{Aa}$ & $1.678 \mathrm{Bb}$ & $1.954 \mathrm{Aa}$ & 1.581 \\
\hline 9 (PA-PF) & $54.333 \mathrm{Bb}$ & $108.667 \mathrm{Aa}$ & $1.000 \mathrm{Ba}$ & $1.067 \mathrm{Aa}$ & $0.337 \mathrm{Ba}$ & $0.520 \mathrm{Ba}$ & $1.656 \mathrm{Ab}$ & $1.774 \mathrm{Aa}$ & 1.225 \\
\hline
\end{tabular}

* Original data processed in X $0.5+$ root for statistical analysis purposes. ** Means followed by at least the same capital letter on the line and in column do not differ according to Tukey's test at $5 \%$ probability. Legend: Hosts: TO: isolates of tomato; EG: isolates of eggplant; PA: isolates of papaya; Origin: Mao: Manaus; Ira: Iranduba; PF: Presidente Figueiredo.

They were kept in a greenhouse during the whole experiment. The inoculum was prepared with conidial suspension concentration adjusted to $10^{4}$ conidia. $\mathrm{mL}^{-1}$ with a hemocytometer. The plants were inoculated at 30 days after germination by manually spraying the inoculum suspension on the adaxial surface and underside of the leaves. Following inoculation, plants were kept in a moist chamber during 48 hours. After this period, they were removed from the humidity chamber and the evaluation began. The reaction was considered positive (presence of symptoms) and negative (absence of symptoms). The number and the diameter of lesions were evaluated. The lesions (length and width) were measured by using a digital caliper (Mitutoyo-CD-8" CX- B model) and counted with a manual assistance counter. Disease severity was assessed according to the adapted Horsfall \& Barrat scale (5), where: 0: no symptoms; $1:<1 \%$ of leaf area affected (LAA); $2: 1-3 \%$ of LAA; 3 : $3-6 \%$ of LAA; $4=6-12 \%$ of LAA; $5=12-25 \%$ of LAA; $6: 25-50 \%$ of LAA and 7: $>50 \%$ LAA. Experimental design was completely randomized in a factorial arrangement of $9 \times 3 \times 3$ ( 9 isolates, 3 areas, 3 hosts) and three replicates; each experimental unit was a plant/ pot. Plants of each host treated with sterile distilled water were the control. Results were statistically analyzed based on SAEG ${ }^{\circledR}$ version 9.0. Treatment means were compared according to Tukey's test at $5 \%$ significance.

All isolates caused disease in their original host (positive reaction). There were no symptoms in papaya plants inoculated with isolates obtained from eggplant (isolated 4, 5 and 6) and tomato (isolates 1,2 and 3), demonstrating a possible degree of host specificity for these isolates. Cutrim \& Silva (1) reported differences in pathogenicity between two tomato isolates and a papaya isolate, similarly to what was observed in our study: tomato isolates were not capable of causing disease in papaya. The isolates from papaya (isolates 7, 8 and 9) were the only ones capable of causing disease in all hosts (eggplant, papaya and tomato) and can be considered non-specific. The same was shown by Duarte et al. (2), who used two isolates of C. cassiicola, a cocoa and another papaya isolate and found that the latter was capable of infecting papaya plants, rubber and cowpea, while the cacao isolate managed to cause disease only in its original host. Silva et al. (8) obtained different results for 16 isolates of C. cassiicola derived from papaya plants, mimosa, rubber and thyme; isolates from papaya and more nine isolates from rubber were not capable of causing disease in eggplant.

Although isolates from papaya have caused disease in all hosts, the most aggressive isolates were obtained from tomato and eggplant. The percentage of affected leaf area was higher in tomato
(2.121), when inoculated with different isolates from Iranduba, and lower in papaya $(1,225)$. Similarly, the largest number of lesions was observed when the eggplant isolate from Iranduba was inoculated in tomato (325). These results demonstrate that the aggressiveness of isolates had geographic influence, suggesting that the isolates from Iranduba City are more aggressive than the other isolates from Presidente Figueiredo and Manaus. The largest diameter of lesion caused by $C$. cassiicola was found in tomato plants when inoculated with eggplant isolate from Manaus (176.7), and the smallest diameter was found in papaya when inoculated with the original isolate from Manaus. Values similar to these were also obtained by Lustosa (6), who found lesions caused by C. cassiicola in Commelina benghalensis L. measuring 0.1-0.6 X 0.1-0.4 cm. The pathogenicity test showed that only papaya isolates were capable of causing disease in all hosts, which suggests that there is possibly some degree of specificity for tomato and eggplant isolates. The disease severity was higher in tomato, and the most aggressive isolates were from Iranduba. The difference in the pathogenicity seen here and the aggressiveness depending on the origin of isolates suggest the occurrence of more than one pathogen population in these areas. To confirm it, new case studies will be conducted at the molecular level of the pathogen, involving the genetic variability and the structure of populations, to understand how these populations have been shaped in the North of Brazil.

\section{REFERENCES}

1. Cutrim, F.A.; Silva, G.S. Patogenicidade de Corynespora cassiicola a diferentes espécies de plantas. Fitopatologia Brasileira, Brasília, DF, v.28, n.2, p.193-194, 2003.

2. Duarte, M.L.R.; Asano, S.; Albuquerque, F.C. Estudos comparativos das características morfológicas e fisiológicas de dois isolamentos de Corynespora cassiicola. Fitopatologia Brasileira, Brasília, DF, v.8, n.2, p.205-214, 1983.

3. Ellis, M.B. Dematiaceous hyphomycetes. Kew: Commonwealth Mycological Institute, 1971. 608p.

4. Farr, D.F.; Rossman, A.Y. Fungal databases, systematic mycology and microbiology laboratory. ARS, USDA, 2006. DiĐ sponível em: <http://nt.ars-grin.gov/fungaldatabases/>. Acesso em: 3 jul. 2016.

5. Horsfall, J.C.; Barratt R.W. Na improved gradig system for measuring plant diseases. Phytopathology, St Paul, v.35, p.665, 1945.

6. Lustosa, D.C. Corynespora cassiicola e Cercospora sp. como 
agentes potenciais para o controle biológico de Commelina benghalensis. 2001. 53f. Dissertação (Mestrado em Fitopatologia) - Universidade Federal de Viçosa, Viçosa.

7. Olive, L.S.; Bain, D.C.; Lefebvre, C.L. A leaf spot of cowpea and soybean caused by undescribed species of Helminthosporium.
Phytopathology, St. Paul, v.35, n.5, p.822-831, 1945.

8. Silva, W.P.K.; Deverall, B.J.; Lyon, B.R. Molecular, physioloe gical and pathological characterization of Corynespora leaf spot fungi from rubber plantations in Sri Lanka. Plant Pathology, UK, v.47, n.3, p.267-277, 1998. 